\title{
A VEGYES SZÓRÁS MINT PROBLÉMA LASCA PERFÚZIOS MÉRÉSEK ESETÉN
}

\author{
Kondász Bence ${ }^{1}$, Hopp Béla ${ }^{1}$, Smausz Kolumbán Tamás ${ }^{1}$ \\ ${ }^{1}$ Szegedi Tudományegyetem, Optika és Kvantumelektronikai Tanszék, Szeged Dóm tér 9., \\ Magyarország
}

DOI: https://doi.org/10.14232/kvantumelektronika.9.20

\section{Bevezetés}

A lézer speckle kontraszt elemzésen (LASCA) alapuló perfúziómérés során a statikus szórás erősen befolyásolja a kapott áramlási értékek pontosságát. Ezen szórástípus élő szövet esetén mindig jelen van, bőr esetén pl. mozdulatlan szöveti rostok, zárványok formájában. A statikus szórás méréstorzító hatásának csökkentésére/kiküszöbölésére különböző módszereket dolgoztak ki. Ilyen pl. a vizsgált szövetek átlátszóságának növelése különböző oldatokkal való átitatásával, aminek a kivitelezése meglehetősen nehézkes. Mérés technikailag jóval egyszerübben alkalmazhatók a statikus szórás hatását is figyelembe vevő, a mért kontraszt expozíciós idő függésén alapuló modellek, mint pl. a több expozíciós időt használó LASCA. Az alábbiakban két ilyen modell alkalmazhatóságát vetjük össze.

Az egyik modellt Parthasarathy és munkatársai [1] dolgozták ki:

$$
K(T)^{2}=\beta \rho^{2} \frac{\tau_{1}^{2}}{2 T^{2}}\left[\exp \left(-\frac{2 T}{\tau_{1}}\right)-1+\frac{2 T}{\tau_{1}}\right]+4 \beta \rho(1-\rho) \frac{\tau_{1}^{2}}{T^{2}}\left[\exp \left(-\frac{T}{\tau_{1}}\right)-1+\frac{T}{\tau_{1}}\right]+v_{\text {noise }}
$$

ahol $\beta$ a mérőrendszere jellemző normalizálási faktor, $\rho=I_{f} /\left(I_{f}+I_{s}\right)$ a dinamikus szóródás aránya a teljes fényintenzitáshoz képest (melynek értéke tisztán statikus szórás esetén 0 , tisztán dinamikus szórás esetén pedig 1), T az expozíciós míg $\tau$ speckle kép időbeli fluktuációját jellemző korrelációs idő. A $v_{\text {noise }}$ a rendszer teljes zaja, amely tartalmazza a kamera müködéséből és a lézer instabilitásából adódó zajokat is. Az áramlási sebességet a korrelációs idő reciprokával szokták jellemezni, melyet speckle kontraszt perfúziós egyégnek (SCPU) hívnak.

A másik kontraszt modell a csoportunk által korábban levezettet egyszerübb, félig empirikus összefüggés [2]:

$$
K(T)^{2}=P_{1}^{2} \frac{\tau_{2}^{2}}{2 T^{2}}\left[\exp \left(\frac{-2 T}{\tau_{2}}\right)-1+\frac{2 T}{\tau_{2}}\right]+P_{2}^{2}
$$

ahol $\mathrm{P}_{1}, \mathrm{P}_{2}$ empirikus illesztési paraméterek, együttesen jellemzik a vizsgált minta szórási paramétereit és a mérőrendszer normálási tényezőjét.

Ezen modellek egyike sem számol a vegyes szórás hatásával. Méréseink során azt vizsgáltuk, hogy különböző dinamikus/statikus szórási arányok hogyan befolyásolják a két modell által szolgáltatott perfúziós értékeket.

\section{Kísérleti paraméterek, elrendezés}

A mérések elvégzésére az 1. ábra vázolt, általunk építtet és fejlesztett kísérleti elrendezést használtuk. 


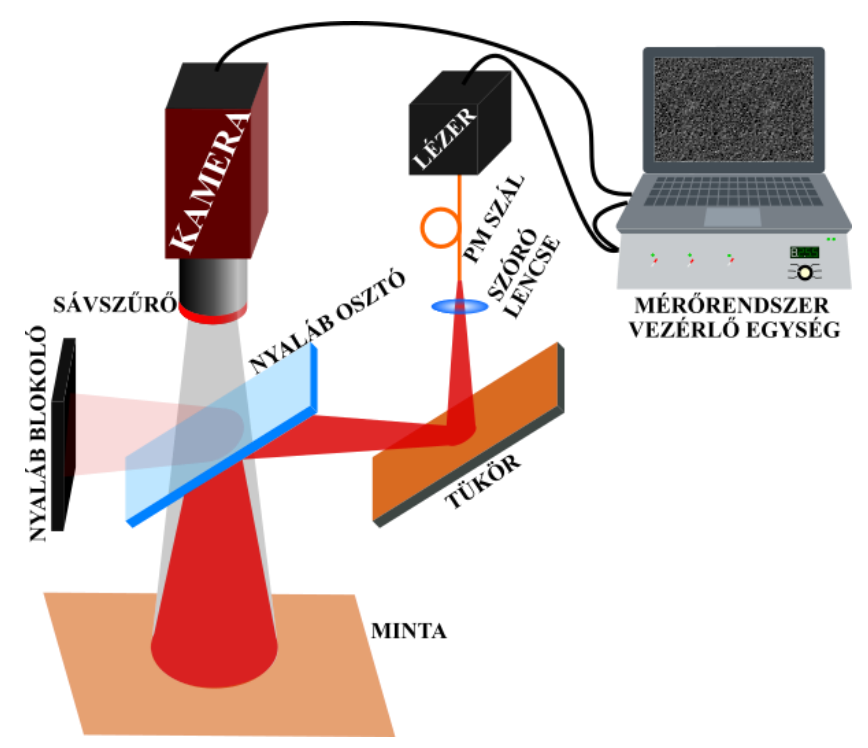

\section{1. ábra A kísérleti elrendezés}

A mintákat egy polarizáció tartó egymódusú optikai szálba becsatolt hőmérséklet és hullámhossz (785 nm) stabilizált lézer dióda fényével világítottuk ki. Egy polarizációs nyalábosztó lap segítségével egy koaxiális rendszert építettünk fel, így elkerülve a vizsgált mintán esetleges árnyékok kialakulását. A képek rögzítésére egy közeli infravörösben érzékenyített sávszürővel ellátott 12 bites monokróm CMOS kamerát használtunk. A lézervezérlést, a képek rögzítését és kiértékelését az általunk LabVIEW környezetben fejlesztett programmal végeztük. A laboratóriumunkban korábban kidolgozott mérési metódust [3] használtuk a több expozíciós időt (1-75 ms mérési tartomány) használó LASCA rendszerünkben.

A mérések során alkalmazott szövet modellünk legfontosabb eleme a $3 \mu \mathrm{m}$ átlagos méretü polisztirén (PS) mikrogömbökből álló szuszpenzió. A szuszpenzió egy $1 \mathrm{~cm}$ vastagságú küvettában volt, melyre különböző, az alkalmazott hullámhosszra áttetsző szóró rétegeket (teflon film, pauszpapír, diffúzor stb.) helyeztünk el, így imitálva az élő szöveti mérések esetének megfelelő dinamikus (áramló vörösvértest) és statikus (börszövet mozdulatlan alkotóelemei) fényszórási komponenseket. Az élő szövetes méréseket kézfejen lévő bőr felületén végeztük el, ugyanazokat a statikus kiegészítő szóró rétegeket használva, mint a fenti modell esetén. A méréseket egy klimatizált állandó hőmérsékleten tartót szobában végeztük el.

\section{Eredmények}

Ahhoz, hogy a saját számolási modellünk összevethető legyen az (1) összefüggéssel, szintén definiáltunk egy dinamikus szórási arányt. A (2) egyenlet aszimptotikus viselkedését felhasználva a következő paramétert vezetjük be:

$$
\rho_{2}=1-\frac{K(\infty)}{K(0)}=1-\frac{P_{2}}{\sqrt{P_{1}^{2}+P_{2}^{2}}}
$$

A fenti összefüggésben $\mathrm{K}(0), \mathrm{K}(\infty)$ a kontraszt határértéke az expozíciós idő 0 -ba és $\infty$-be tartása esetén, melyek a 2. ábran lévő kontraszt görbéken grafikusan is ábrázolunk. Amint látható, egy intenzíven szóró statikus fedőréteg hatására a $K(\infty)$ jelentősen megnő, a görbe $K(0)-K(\infty)$ dinamikai tartománya pedig jelentősen lecsökken. Habár matematikailag eltérő formájú, de a $\rho_{2}$ szerepe és viselkedése hasonló az (1) összefüggésben leírt dinamikus szórási arányhoz, azaz az értékük teljesen dinamikus szórás esetén 1, kizárólag mozdulatlan szórócentrumok jelenléte esetén pedig 0 lenne. 


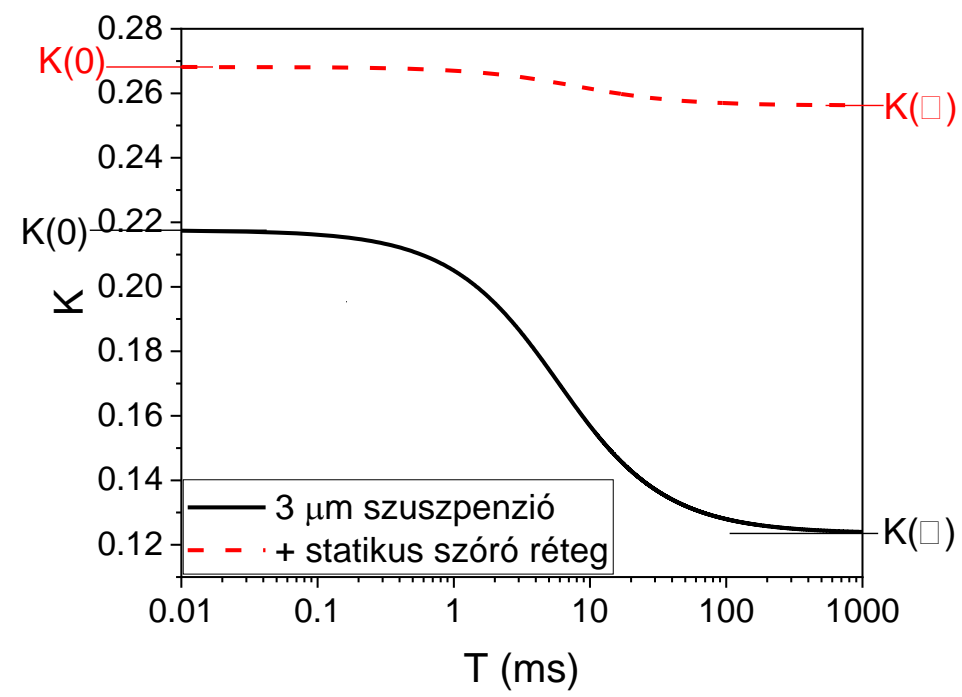

2. ábra Kontraszt görbék statikus szóró réteg jelenlétében és fedetlen mikrogömb szuszpenzió esetén

A különböző expozíciós idők esetén mért kontraszt értékekre a két modell (az (1) és (2) egyenletek) függvénye gyakorlatilag teljesen átfedve illeszkedik, csekély mértékben csak az alacsony expozíciós idejü régióban $(<1 \mathrm{~ms})$ térnek el egymástól, viszont az illesztésekkel kapott $\tau$ korrelációs idők tendenciózusan különböznek mind a szövet modell, mind pedig a bőrfelületen mért adatok esetén.
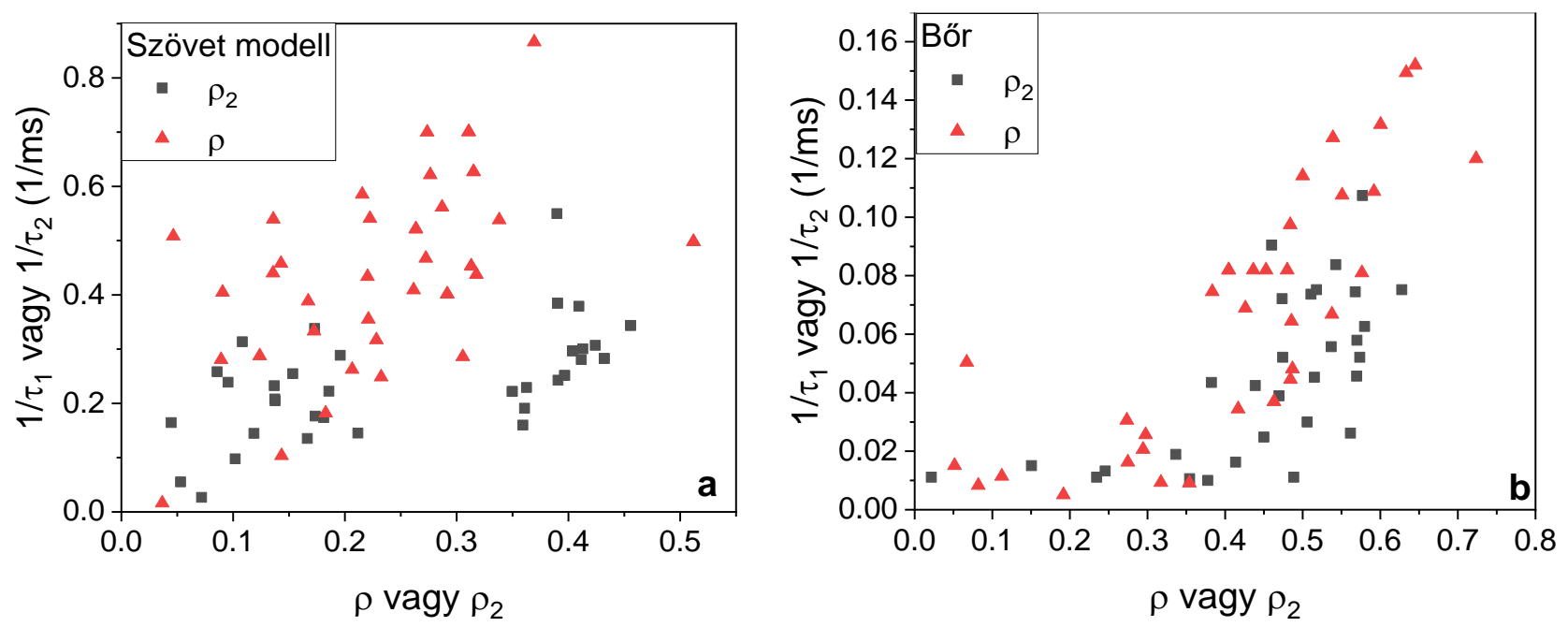

3. ábra A SCPU viselkedése különbözö statikus szóró rétegek esetén modell- (a) és élő (b) szövet használatakor

Az illesztések alapján kapott SCPU és dinamikus hozzájárulás ( $\rho$ és $\rho_{2}$ ) értékeket ábrázolva mindkét számolási modell hasonlóviselkedést mutat, azaz ahogy egyre jobban szóró réteget helyezünk a szuszpenzióra, annál jobban csökkent a mért perfúziós érték (3. ábra). Az ábrán jól látható, hogy a teljesen dinamikus szórás elméletileg $\rho=\rho_{2}=1$ esetét nem sikerült elérni, ennek oka lehet, hogy a mérés során a mikrogömbök kitapadhattak a küvetta falán, illetve küvetta alatti fehér papírlap további statikus szóró rétegként viselkedhetett. A bőrfelületen elvégzett mérések esetén a modellek illeszkedésében hasonlót tapasztaltunk, mint a szuszpenzió esetén: a $\rho$ és $\rho_{2}$ dinamikus szórási aránnyal együtt változik a mért áramlási sebesség (3. ábra), de a tendencia némileg eltérő. Ez azzal magyarázható, hogy míg a szövet modell esetén a statikus szóróréteg fedi a szuszpenziót, bőr esetén már fedetlen állapotban is van statikus szórás úgy, hogy a szóró részek és mozgó vörösvértestek térben keverednek. 
A mért áramlási sebesség tartományt egy $0,65 \mu \mathrm{m}$ átlagos méretü PS mikrogömbökből álló szuszpenzió alkalmazásával kibővítve jól látható (4. ábra), hogy a két modell által adott korrelációs idő értékek között egyenes arányosság áll fenn, valamint jó korrelációt mutatnak a számolt dinamikus szórási paraméterek is (4. ábra). Mind ezt azt jelenti, hogy a csoportunk által bevezetett egyszerübb kontraszt modell (2) ugyanolyan pontosságú eredményt ad, mint a jóval bonyolultabb, nehezebben illeszthetö (1) összefüggés
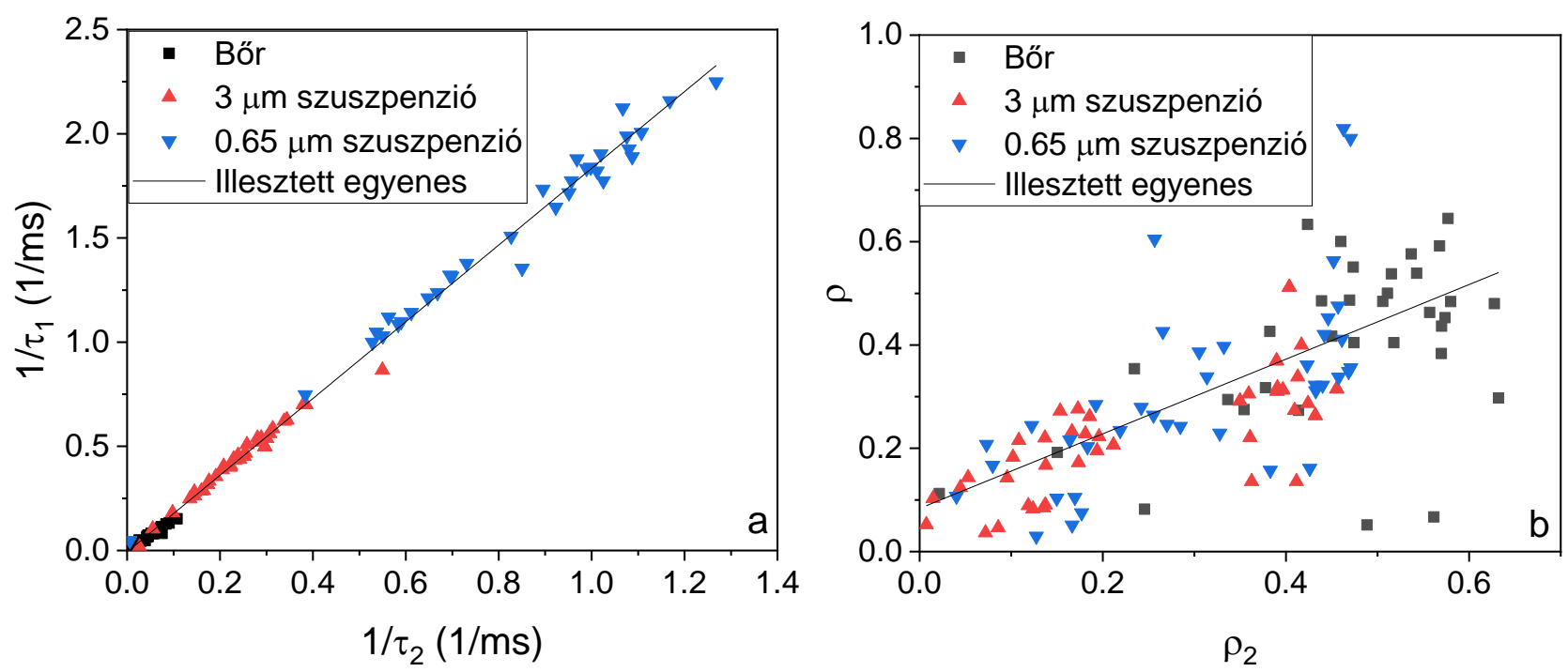

4. ábra A két kontraszt modell azonos jelentésü tagjai: SCPU (a) és dinamikus szórási arányok (b) közötti összefüggés

\section{4. Összefoglalás}

Szöveti modell és bőrfelület esetén is kimutattuk, hogy mindkét kontraszt modellnél a mért áramlási sebesség függ a mozdulatlan szórócentrumok jelenlététől, azaz a dinamikus szórási aránytól. Ez arra utal, hogy a vegyes szórásnak, - amikor is az egyes fotonok mozdulatlan és mozgó részeken egyaránt szóródnak - jelentős hozzájárulása van a speckle interferenciaképek kialakulásában. A két vizsgált számolási modell a statikus szórás hozzájárulásának a kiküszöbölésére lett bevezetve, azonban a vegyes szórással nem tudnak számolni. A vegyes szórás részletesebb vizsgálata céljából egy módosított szövetmodell összeállításán dolgozunk, mellyel külön-külön tudjuk kezelni az egyes komponensek hozzájárulását az interferenciakép kialakulásához.

\section{Köszönetnyilvánítás}

A kutatás EFOP-3.6.1-16-2016-00008 azonosítószámú „Intelligens élettudományi technológiák, módszertanok, alkalmazások fejlesztése és innovatív folyamatok, szolgáltatások kialakítása a szegedi tudásbázisra építve" címü pályázat támogatásával készült.

\section{Irodalom}

[1] A. B. Parthasarathy, W. J. Tom, A. Gopal, X. Zhang, and A. K. Dunn, Opt. Express 16, 1975 (2008). https://doi.org/10.1364/OE.16.001975

[2] T. Smausz, D. Zölei, and B. Hopp, Appl. Opt. 48, 1425 (2009). https://doi.org/10.1364/AO.48.001425

[3] D. Zölei, T. Smausz, B. Hopp, and F. Bari, J. Eur. Opt. Soc. Rapid Publ. 8, 13053 (2013). https://doi.org/10.2971/jeos.2013.13053 